\title{
PELATIHAN PEMBUATAN BAHAN AJAR MENGGUNAKAN FILMORA KEPADA GURU MADRASAH ALIYAH (MA) TANBIHUL GHOFILIIN, KABUPATEN BANJARNEGARA
}

\author{
Sarmini'1), Niken Lia Prihatiningtias Pembayun"1), Nilam Puspita Nurdewanti1) \\ 1)Program Studi Sistem Informasi, Fakultas IImu Komputer, Universitas Amikom Purwokerto, Banyumas, \\ Jawa Tengah, Indonesia \\ Corresponding author: Sarmini \\ E-mail : sarmini@amikompurwokerto.ac.id
}

Diterima 14 Juni 2021, Direvisi 28 Juni 2021, Disetujui 30 Juni 2021

\begin{abstract}
ABSTRAK
Beberapa kendala dialami oleh guru-guru di MA Tanbihul Ghofiliin dengan adanya perubahan model pembelajaran tersebut diantara adalah bagaimana membuat materi pembelajaran yang menarik dan tidak monoton yang hanya berupa teks disampaikan dalam powerpoint ataupun file dokumen word atau pdf. Pelatihan pembuatan bahan ajar menggunakan Filmora kepada guru MA Tanbihul Ghofiliin Banjarnegara bertujuan untuk meningkatkan kemampuan guru dalam membuat bahan ajar berupa video pembelajaran. Kegiatan pelatihan dilaksanakan pada hari Sabtu tanggal 5 Juni 2021 di Laboratorium Komputer 2 MA Tanbihul Ghofiliin Banjarnegara yang diikuti oleh 9 orang peserta yaitu bapak dan ibu guru MA Tanbihul Ghofiliin. Kegiatan pelatihan dilakukan dengan mempraktikkkan langsung bagaimana cara mengedit video menggunakan aplikasi Filmora, dari tahap membuat video pembuka sampai dengan video penutup hingga menambahkan efek-efek dalam video serta rendering video. Berdasarkan hasil pengamatan selama kegiatan berjalan dan juga jawaban peserta, kegiatan pelatihan dapat diikuti dengan baik oleh peserta, dimana peserta dapat mengikuti setiap tahapan editing video hingga akhir menjadi sebuah video utuh. Tanggapan positif diberikan oleh peserta yang antusias dan berharap akan ada pelatihan-pelatihan pemanfaatan teknologi lainnya yang dapat menunjang proses kegiatan belajar mengajar khususnya di masa pandemi covid-19.
\end{abstract}

Kata kunci: bahan ajar; filmora; editing; pelatihan; video.

\begin{abstract}
Some of the obstacles experienced by the teachers at MA Tanbihul Ghofiliin with the changes in the learning model, including how to make learning materials that are interesting and not monotonous, which are only in the form of text delivered in powerpoint or word or pdf document files. Training on making teaching materials using Filmora for MA Tanbihul Ghofiliin Banjarnegara teachers aims to improve the ability of teachers to make teaching materials in the form of learning videos. The training activity was carried out on Saturday, June 5, 2021 at the Computer Laboratory of MA Tanbihul Ghofiliin Banjarnegara which was attended by 9 participants, namely the teacher of MA Tanbihul Ghofiliin. The activity was carried out by practicing directly how to make videos using the Filmora application, from the stage of making the opening video to closing the video to adding effects in the video and rendering the video. Based on observations during the activity as well as participants' answers, the training activities can be followed well by the participants, where participants can follow each stage of video editing until the end becomes a complete video. The positive response was given by enthusiastic participants and hoped that there would be trainings on the use of other technologies that could support the teaching and learning process, especially during a pandemic Covid-19.
\end{abstract}

Keywords: training; editing; videos; teaching materials; filmora.

\section{PENDAHULUAN}

Pandemi Covid-19 yang sedang terjadi saat ini telah ditetapkan sebagai bencana nasional non-alam oleh Presiden Republik Indonesia (Nissa, 2020). Semua sektor kehidupan terkena imbas dari pandemi ini tidak terkecuali bidang pendidikan. Dampak yang sangat besar dirasakan adalah adanya perubahan proses pembelajaran yang dilakukan dimana sebelumnya ada pandemi dilakukan dengan tatap muka, setelah adanya pandemi dilakukan dengan Pembelajaran Jarak Jauh (PJJ), baik dengan pembelajaran daring (dalam jaringan) maupun luring (luar jaringan). Sesuai dengan Surat Keputusan Bersama (SKB) 4 Menteri guna memastikan hak belajar 
setiap anak terpenuhi, sekolah harus mampu mengoptimalkan dua sistem pembelajaran tersebut (Mulyana, 2020). Sekolah yang masih belum siap dengan segala sarana dan prasarana (sarpras) yang memadai, mau tidak mau saat ini harus mempersiapkan segala sarpras pembelajaran dengan dua sistem tersebut. Tidak terkecuali dengan peran guru, guru yang awalnya acuh tak acuh dengan pembelajaran daring (atau berkaitan dengan teknologi informasi) sebelum masa pandemi, saat ini guru harus mau beradaptasi dengan sistem pembelajaran tersebut.

Selain masih belum siapnya sarpras sekolah, beberapa kendala yang timbul dalam pelaksanaan PJJ di antaranya kebingungan guru dalam mengelola PJJ, para peserta didik juga mengalami kesulitan berkonsentrasi belajar dari rumah, meningkatnya rasa jenuh/bosan karena materi pembelajaran yang tidak menarik dan monoton berupa teks atau hanya sekedar gambar. Kemudian kendala berikutnya adalah orang tua yang tidak bisa secara optimal mendampingi anak-anak belajar di rumah karena harus bekerja ataupun kemampuan sebagai pendamping belajar anak yang kurang. Oleh karenanya, peran sekolah dan guru sangat penting untuk proses pengembangan potensi peserta didik. Media pembelajaran yang sebelum pandemi didemonstrasikan secara langsung, setelah pandemi dilakukan dengan pemanfaatan media berbasis teknologi informasi sehingga menuntut sekolah dan guru harus kreatif (Mutia et al., 2017). Maka dari itu untuk dapat meningkatkan kemampuan dan kreativitas guru dalam proses pembelajaran maka guru dapat belajar untuk membuat media pembelajaran kreatif yang berbasis teknologi informasi sederhana seperti pembuatan materi pembelajaran dalam bentuk video.

Salah satu alternatif agar pembelajaran dapat berlangsung secara efektif dan efisien yaitu menggunakan media video pembelajaran(Taufik, 2016). Video merupakan salah satu media pembelajaran audio visual yang diminati dalam proses pembelajaran, sebab video memudahkan secara visual bagi peserta dalam memahami sebuah materi(Rosali, 2020)(Busyaeri et al., 2016). Melalui media video proses pembelajaran lebih menarik dan menyenangkan, informasi yang disampaikan secara lisan terkadang tidak dipahami sepenuhnya oleh siswa, terlebih lagi guru kurang cakap dalam memperjelas materi, maka media berperan sebagai alat bantu untuk memperjelas pesan yang disampaikan dalam proses belajar mengajar(Hardianti \& Asri, 2017). Selain itu keunggulan media pembelajaran dengan menggunakan video adalah mudah digunakan dan mampu menjelaskan konten dengan lebih nyata(Batubara \& Ariani, 2016). Selain itu disebutkan bahwa pembelajaran dengan menggunakan media video lebih baik dibandingkan dengan tidak menggunakan media video(Agustiningsih, 2015). Dalam penelitian yang lain juga disampaikan bahwa hasil pembelajaran siswa yang dibelajarkan dengan menggunakan video lebih efektif dibandingkan dengan hasil pembelajaran siswa yang dibelajarkan dengan menggunakan animasi(Lubis, 2017). Penerapan pemanfaatan video sebagai media pembelajaran juga dapat meningkatkan minat belajar dan hasil belajar siswa pada mata pelajaran menggambar teknik dasar(Sipayung \& Darwin, 2016). Dan berikutnya juga dijelaskan bahwa terdapat pengaruh penggunaan media pembelajaran audio visual video terhadap hasil belajar subtema 1 keberagaman budaya bangsaku(Novita et al., 2019).

MA Tanbihul Ghofiliin adalah salah satu lembaga pendidikan yang setingkat/setara dengan SMA/SMK yang ada di kabupaten Banjarnegara tepatnya berada di Kecamatan Bawang. Perubahan proses Kegiatan Belajar Mengajar (KBM) juga dilakukan oleh MA Tanbihul Ghofiliin dengan adanya pandemi Covid-19 ini, dimana proses KBM sebelumnya dilakukan dengan tatap muka menjadi daring. Beberapa kendalapun dialami oleh guru-guru di MA Tanbihul Ghofiliin dengan adanya perubahan model pembelajaran tersebut diantara adalah bagaimana membuat materi pembelajaran yang menarik dan tidak monoton yang hanya berupa teks disampaikan dalam powerpoint ataupun file dokumen word atau pdf. Kendala lainnya adalah dimana guru untuk beberapa mata pelajaran merasa kesulitan untuk menjelaskan materinya karena membutuhkan media untuk mempraktikkan materi yang disampaikan agar mudah untuk dipahami oleh siswa.

Maka dari itu dibutuhkan sebuah pelatihan kepada guru-guru di MA Tanbihul Ghofiliin yang dapat meningkatkan kemampuan guru-guru disana dalam membuat bahan ajar dalam bentuk video pembelajaran. Pada kegiatan Amikom Mitra Masyarakat sebelumnya telah diberikan kepada guru-guru di MA Tanbihul Ghofiliin yaitu pelatihan Google Apps for Education juga telah disampaikan oleh perwakilan pihak sekolah bahwasanya harapan mereka setelah mereka mengenal berbagai kegunaan dan manfaat dari Google Apps for Education untuk pembelajaran daring, mereka berharap kegiatan pelatihan dapat berlanjut pada pelatihan pembuatan bahan ajar berupa video pembelajaran. Kegiatan pelatihan yang dilakukan diharapkan dapat meningkatkan 
kemampuan guru dalam membuat bahan ajar berupa video yang bagus dan menarik sehingga guru-guru dapat memberikan materi dan model pembelajaran dengan cara yang lebih menyenangkan dan mudah dipahami oleh siswa sehingga siswa dapat termotivasi dan tetap antusias untuk terus belajar meski melalui media pembelajaran daring.

Berdasarkan pada analisis situasi yang telah dipaparkan di atas, maka untuk dapat meningkatkan kemampuan guru dalam membuat bahan ajar berupa video pembelajaran maka perlu dilaksanakan kegiatan Amikom Mitra Masyarakat berupa Pelatihan Pembuatan Bahan Ajar Menggunakan Filmora Kepada Guru Madrasah Aliyah (MA) Tanbihul Ghofiliin Banjarnegara. Pabane (2020) menyebutkan ada 8 alasan mengapa aplikasi edit video Filmora cocok untuk pemula dalam mengedit video yaitu diantaranya adalah Filmora memiliki tampilan dan fitur yang sesuai kebutuhan dengan tampilan yang sederhana serta berbagai tool mudah untuk dikenali. Selain itu dijelaskan pula bahwa aplikasi Filmora ringan sehingga dapat dijalankan di perangkat yang memiliki spesifikasi rendah dan tersedia berbagai plugin bawaan yang gratis (Pabane, 2020).

\section{METODE PELAKSANAAN}

Untuk merealisasikan solusi yang ditawarkan dan menyelesaikan permasalahan yang ada pada mitra maka dilaksanakanlah kegiatan pelatihan pembuatan bahan ajar menggunakan Filmora kepada guru Madrasah Aliyah (MA) Tanbihul Ghofiliin Banjarnegara. Dalam kegiatan pelatihan ini diberikan pelatihan bagaimana cara mengedit video dari menggabungkan beberapa video, memotong video, menambahkan teks, gambar, efek tulisan, suara maupun backsound ke dalam video. Kemudian bagaimana melakukan rendering video sampai menjadi video pembelajaran yang siap untuk disampaikan kepada siswa.

Pada pelaksanaan kegiatan pelatihan ini digunakan pendekatan partisipatif yaitu pendekatan yang berorientasi kepada upaya peningkatan peran serta masyarakat secara langsung dalam berbagai proses dan pelaksanaan pengabdian. Dimana para peserta kegiatan pelatihan turut partisipatif untuk mempraktekan setiap tahapan-tahapan dalam pembuatan bahan ajar berupa video pembelajaran dengan menggunakan aplikasi filmora yang didemokan oleh tim pelaksana kegiatan. Pelatihan ini diharapkan dapat meningkatkan kemampuan guru-guru di MA Tanbihul Ghofiliin dalam membuat bahan ajar berupa video pembelajaran sehingga mereka dapat membuat materi-materi pembelajaran dengan kreatif dan lebih menarik serta materi tersampaikan dengan baik kepada siswa. Besar harapan dengan pelatihan ini kemampuan guru-guru MA Tanbihul Ghofiliin dalam pemanfaatan teknologi informasi di dunia pendidikan semakin meningkat dan dapat diimplementasikan dengan baik untuk menunjang kemajuan belajar dan prestasi siswa serta mencapai tujuan MA Tanbihul Ghofiliin untuk menghasilkan lulusan-lulusan yang terbaik.

Untuk mengetahui sejauh mana tingkat penerimaan peserta pada kegiatan pelatihan yang diberikan, maka perlu adanya evaluasi yang dilakukan oleh tim pelaksana kegiatan. Adapun metode evaluasi yang dilakukan adalah dengan melakukan observasi dan tanya jawab kepada peserta pelatihan. Metode observasi dilakukan selama kegiatan pelatihan berjalan dengan mendatangi setiap peserta pelatihan untuk mengetahui apakah ada kesulitan atau kendala yang dialami oleh peserta. Sedangkan sesi tanya jawab bertujuan untuk memberikan kesempatan kepada peserta untuk bertanya kepada tim pelaksana jika ada hal yang peserta tidak ketahui dan pahami dari materi yang disampaikan. Adapun indikator yang digunakan untuk mengetahui bahwa peserta telah dapat menerima dengan baik materi dan praktik yang disampaikan adalah bahwa peserta mampu mengikuti setiap tahapan editing video hingga menghasilkan video utuh. Dan pelatihan dapat dikatakan berhasil jika $80 \%$ dari jumlah peserta mampu menyelesaikan editing video hingga menjadi video yang siap untuk digunakan.

\section{HASIL DAN PEMBAHASAN}

Pelaksanaan kegiatan pelatihan pembuatan bahan ajar menggunakan aplikasi Filmora kepada guru di MA Tanbihul Ghofiliin dilaksanakan pada hari Sabtu, tanggal 5 Juni 2021 di ruang Laboratorium Komputer 2 MA Tanbihul Ghofiliin Banjarnegara. Kegiatan pelatihan dimulai pada pukul $10.00-12.00$ WIB yang diikuti oleh 9 peserta yang merupakan Bapak dan Ibu guru pengajar di MA Tanbihul Ghofiliin.

$$
\text { Kegiatan pelatihan dilakukan }
$$

dengan membuka kegiatan pelatihan oleh tim pelaksana kegiatan yang kemudian dilanjutkan dengan kegiatan inti yaitu pengenalan aplikasi Filmora secara singkat. Setelah peserta mengetahui tentang apa itu aplikasi Filmora, kemudian pelatihan dilanjutkan dengan praktik langsung bagaimana melakukan edit video dengan menggunakan aplikasi Filmora. Pada tahap awal peserta diarahkan untuk membuka aplikasi filmora, sebelum melanjutkan tahap selanjutnya peserta diberikan penjelasan 
bahwasanya dalam sebuah video terdiri dari 3 komposisi yaitu pembukaan, isi dan penutup.

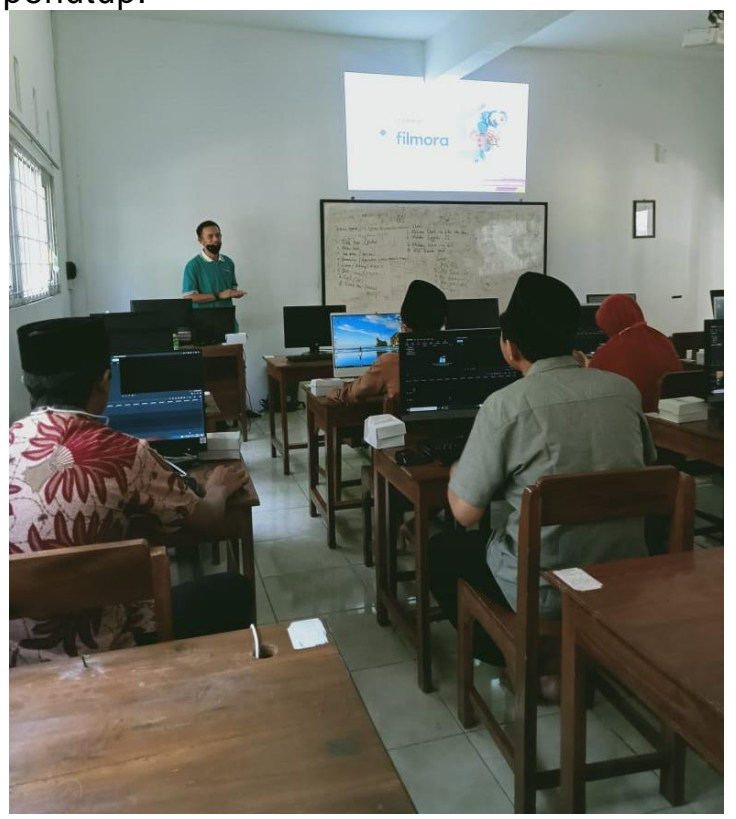

Gambar 1. Pengenalan Aplikasi Filmora

Tahap selanjutnya adalah inti dari kegiatan pelatihan yaitu melakukan editing video, dimana peserta diarahkan untuk membuat lembar kerja baru. Setelah lembar kerja baru dibuat maka peserta diarahkan untuk membuat video pembuka dengan mengambil salah satu contoh video pembuka yang telah ada didalam aplikasi Filmora. Kemudian setelah video pembuka maka peserta diminta untuk menambahkan video sebagai konten atau isi dari video yang akan dibuat dan tidak lupa juga menambahkan video penutup. Pada proses pengeditan video peserta diajarkan bagaimana menambahkan efek di dalam video agar video dapat terlihat lebih menarik seperti efek transisi ketika ada perpindahan dari frame satu ke frame lainnya, menambahkan elemen dan juga bagaimana menambahkan efek suara atau backsound agar video semakin lebih menarik.

Peserta juga diajarkan bagaimana menambahkan tulisan didalam video serta bagaimana menghilangkan efek suara dari video. Setelah penambahan efek pada video selesai dilakukan peserta diminta untuk menambahkan satu frame sebagai video penutup. Dan setelah semua tahapan proses edit video selesai dilakukan maka peserta dapat melakukan export video. Proses export video ini adalah untuk menyimpan video agar dapat dibuka di pemutar video. Setelah peserta diajarkan bagaimana melakukan export video, selanjutnya peserta diajarkan bagaimana cara untuk menyimpan file video yang telah di edit, hal ini dilakukan jika suatu saat peserta akan mengedit kembali video peserta dapat dengan mudah tinggal membuka file yang telah tersimpan tanpa menyusun ulang dari awal.

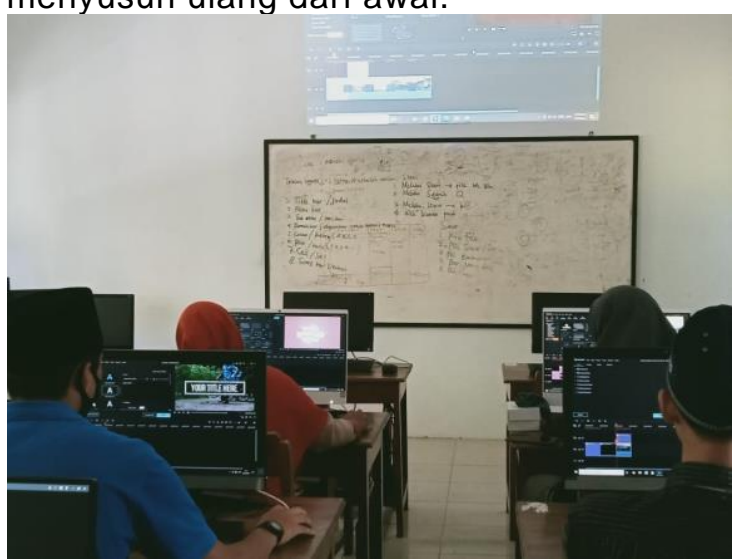

Gambar 2. Praktik Langsung Editing Video

Kegiatan pelatihan pembuatan bahan ajar menggunakan Filmora dapat berjalan dengan lancar dan diikuti dengan baik oleh seluruh peserta. Peserta terlihat antusias dan cepat dalam mengikuti tahapan-tahapan yang disampaikan oleh tim pelaksana. Di akhir kegiatan tim pelaksana kegiatan memberikan kesempatan untuk bertanya jawab dengan peserta, pada sesi tanya jawab ini ada beberapa pertanyaan yang disampaikan oleh peserta, seperti bagaimana jika akan melakukan edit video yang sebelumnya, apakah harus membuat lembar kerja baru?. Dari sesi tanya jawab yang dilakukan, tim pelaksana juga dapat menyimpulkan bahwa seluruh materi yang disampaikan dapat diterima dan peserta juga dapat mempraktikkannya dengan baik hingga akhir kegiatan.

Berdasarkan pada hasil pengamatan yang dilakukan selama kegiatan berjalan tidak ditemui kendala yang berarti baik kendala teknis maupun kendala lainnya. Kegiatan pelatihan dapat berjalan dengan lancar meski butuh kesabaran untuk membimbing peserta dengan perlahan dalam mempraktikkan setiap tahapan yang dijelaskan oleh tim pelaksana dikarenakan peserta masih baru mengenal dan menggunakan aplikasi Filmora sebagai alat bantu untuk melakukan edit video. Secara presentase sekitar $90 \%$ peserta pelatihan dapat menyelesaikan semua tahapan editing video hingga pada proses rendering video untuk menjadi video utuh yang siap untuk ditonton. Selain itu, berdasarkan pada sesi tanya jawab peserta dengan tim pelaksana dapat diketahui bahwa pelatihan pembuatan bahan ajar menggunakan aplikasi Filmora telah memberikan dampak positif kepada peserta 
dimana peserta mendapatkan pengetahuan dan ketrampilan baru dalam pembuatan bahan ajar khususnya adalah media pembelajaran dengan video pembelajaran. Secara keseluruhan pelatihan yang dilaksanakan dapat dikatakan berhasil dikarenakan tersampaikannya tujuan dan manfaat dari kegiatan pelatihan ini kepada peserta. Pelaksanaan kegiatan pelatihan dapat dikatakan berhasil apabila dalam diri peserta pelatihan terjadi suatu proses transformasi pengalaman belajar pada bidang pekerjaan(Siagian, 1994).

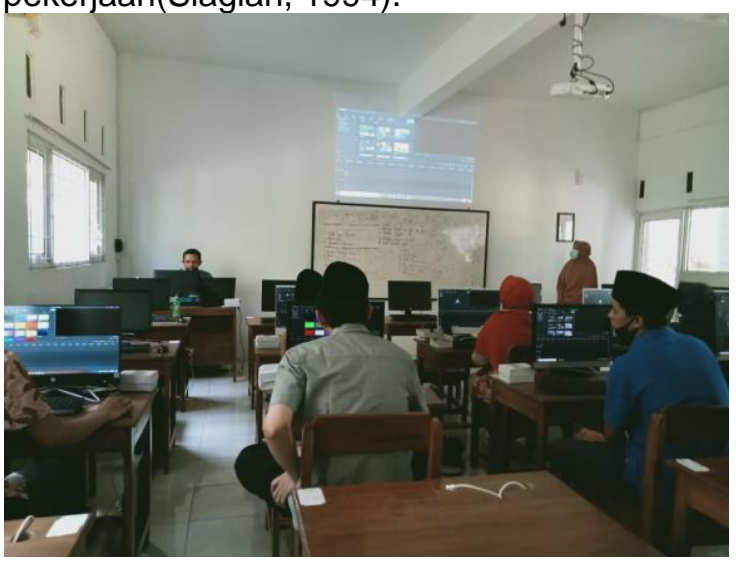

Gambar 3. Proses Rendering Video

\section{SIMPULAN DAN SARAN Simpulan}

Berdasarkan dari hasil pelaksanaan kegiatan Amikom Mitra Masyarakat "Pelatihan Pembuatan Bahan Ajar Menggunakan Filmora Kepada Guru di MA Tanbihul Ghofiliin Banjarnegara yang dilaksanakan pada hari Sabtu, tanggal 5 Juni 2021 bertempat di Laboratorium Komputer 2 MA Tanbihul Ghofilin Banjarnegara mendapatkan tanggapan yang positif dan dapat diikuti dengan baik oleh seluruh peserta. Peserta tampak antusias dalam mengikuti seluruh rangkaian kegiatan pelatihan editing video dari awal kegiatan dimulai hingga akhir kegiatan. Peserta dapat mengikuti setiap tahapan dalam editing video dengan baik, dari membuat video pembuka, isi hingga video penutup serta menambahkan efek-efek dalam video seperti efek menambahkan tulisan didalam video, efek transisi dan efek-efek lainnya yang dapat membuat video lebih menarik untuk dilihat hingga pada tahap akhir yaitu tahap rendering video agar video dapat diputar dalam pemutar video.

\section{Saran}

Adapun saran dari kegiatan Amikom Mitra Masyarakat adalah bahwasanya kegiatan pelatihan editing video ini dapat dilaksanakan secara berkelanjutan dengan pelatihan editing video lanjutan agar peserta semakin lebih mahir dalam editing video dan dapat menghasilkan video yang bagus dan menarik untuk dinikmati.

\section{UCAPAN TERIMAKASIH}

Ucapan terima kasih penulis sampaikan kepada Lembaga Penelitian dan Pengabdian Masyarakat Universitas Amikom Purwokerto dan Universitas Amikom Purwokerto atas segala dukungannya baik materil dan moril dalam pelaksanaan kegiatan Amikom Mitra Masyarakat ini sehingga dapat berjalan dengan baik dan lancar.

\section{DAFTAR RUJUKAN}

Agustiningsih. (2015). Video Sebagai Alternatif Media Pembelajaran Dalam Rangka Mendukung Keberhasilan Penerapan Kurikulum 2013 di Sekolah Dasar. Pancaran, 4(1), 55-68.

Batubara, H. H., \& Ariani, D. N. (2016). Pemanfaatan Video sebagai Media Pembelajaran Matematika SD/MI. Muallimuna: Jurnal Madrasah Ibtidaiyah, 2(1), 47-66.

Busyaeri, A., Udin, T., \& Zaenuddin, A. (2016). Pengaruh Penggunaan Video Pembelajaran Terhadap Peningkatan Hasil Belajar Mapel IPA di MIN Kroya Cirebon. Al Ibtida, 3(1), 116-137.

Hardianti, \& Asri, W. K. (2017). Keefektifan Penggunaan Media Video dalam Keterampilan Menulis Karangan Sederhana Bahasa Jerman Siswa Kelas XII IPA SMA Negeri 11 Makasar. Eralingua: Jurnal Pendidikan Bahasa Asing Dan Sastra, 1(2), 123-130.

Lubis, S. P. W. (2017). Pengaruh Penggunaan Video Pembelajaran Terhadap Hasil Belajar Siswa Kelas XII. Jurnal Dedikasi, 1(2), 169-174.

Mulyana, A. (2020). Isi Surat Keputusan Bersama 4 Menteri Tentang Panduan Penyelenggaraan Pembelajaran pada Tahun Ajaran 2020/2021.

Mutia, R., Adlim, \& Halim, A. (2017). Pengembangan Video Pembelajaran Ipa Pada Materi Pencemaran Dan Kerusakan Lingkungan. Jurnal Pendidikan Sains Indonesia, 5(2), 108-114.

Nissa, N. K. (2020). Dampak Perubahan Pola Mobilitas Masyarakat Indonesia terhadap Sektor Transportasi saat Pandemi COVID-19.

Novita, L., Sukmanasa, E., \& Pratama, M. Y. (2019). Penggunaan Media Pembelajaran Video terhadap Hasil Belajar Siswa SD. Indonesian Journal of Primary Education, 3(2), 64-72.

Pabane, I. (2020). 8 Alasan Filmora adalah 
Aplikasi Video Editor Terbaik Bagi Pemula.

Rosali, E. S. (2020). Aktifitas Pembelajaran Daring Pada Masa Pandemi Covid-19 di Jurusan Pendidikan Geografi Universitas Siliwangi Tasikmalaya. Geography Science Education Journal (GEOSEE), 1(1), 21-30.

Siagian, S. P. (1994). Administrasi Pembangunan.

Sipayung, O., \& Darwin. (2016). Pemanfaatan Video Sebagai Media Pembelajaran Untuk Meningkatkan Minat Belajar dan Hasil Belajar Siswa Pada Mata Pelajaran Menggambar Teknik Dasar Kelas X Program Keahlian Konstruksi Batu dan Beton SMK Negeri 2 Pematangsiantar. Jurnal Educational Building, 2(1), 87-93.

Taufik, D. K. (2016). Pengaruh Penggunaan Media Video Pembelajaran Terhadap Prestasi Belajar IImu Pengetahuan Sosial Siswa Kelas V SD Se-Kecamatan Gedangsari Gunungkidul. Jurnal Pendidikan Ke-SD-An, 3(1), 21-26. 